\title{
Profitability through matching feed supply to animal requirement
}

N. MCLAREN

Agriculture New Zealand, PO Box 649, Masterton

\begin{abstract}
Summer dry Wairarapa hill country can be farmed profitably. Most of the profit is created by fully feeding the stock in the spring from September to early December. My economic farm surplus to total capital involved has given me a return of 8 $11 \%$ over the last 4 years. The key ingredient is to maximise the most profitable enterprise and then fit the other stock options around it. I maintain that a 2-year cattle finishing policy fits the pasture growth pattern best and achieves the desired financial results.
\end{abstract}

Keywords: animal requirements, feed supply, profitability

\section{Introduction}

1 have farmed Middlespur, located at the back of Gladstone, since 1979 when I bought my brothers out of the family trust. Middlespur is a typical Wairarapa hill country farm, summer dry and winter wet. The property is 401 ha effective with 40 ha of native bush, big scrub and retirement with no country that can be cut for hay or silage. Stock types and numbers are shown in Table 1.

I have 8.9 ha of top river silt at Te Whiti near Masterton where I live and this is used intensively to finish bulls. I have been producing around $450-500 \mathrm{~kg}$ of carcass weight per ha per year off this block but it is all treated as one property with the main block.

The current objective is to maintain a high net return of $\$ 150$ plus per ha and to be reducing debt as quickly as possible. The present net return is allowing me to do this. This return has been achieved with a high ratio of bulls (43\%) doing average production. The $57 \%$ of sheep stock units have tended to be treated as second class citizens at certain times of the year to ensure I achieve good cattle income.

The farming target is to increase present production by $10 \%$ over the next 2 years. The key points are stock liveweights, selling dates and selling flexibility. The bull liveweight targets are $110 \mathrm{~kg}$ by 1 December, 220 $\mathrm{kg}$ by 1 June, $350 \mathrm{~kg}$ by 1 December, $400 \mathrm{~kg}$ by 1 September as a 2 year old. By late October at least 25\% of bulls should be better than $570 \mathrm{~kg}$ liveweight and by mid January $75 \%$ at better than $300 \mathrm{~kg}$ carcass weight.
The sheep targets are mixed age ewes at tupping 58-60 $\mathrm{kg}$ and 2 th's $55 \mathrm{~kg}$. The different liveweights required throughout the year to achieve these target weights are outlined in Tables 3 and 4.

\section{Soils and fertiliser}

The soil type is basically mudstone Taihape steepland silt loam and Atua silt loam which is very wet in the winter and dry in the summer. It is erosion prone but the better natural fertility does mean that slips heal relatively quickly. Traditionally the fertiliser policy was $375 \mathrm{~kg}$ per ha of superphosphate every second year. I have been using DAP since 1980 and basically doing a third or a half the farm each year. Superphosphate has been used once since then and I have also added some Amsulf and urea into the DAP on the odd occasion to provide more cattle feed. The DAP has been applied to the better back half of the property at $60 \mathrm{~kg}$ per ha $(12 \mathrm{~kg}$ available phosphorus (P)/ha and $11 \mathrm{~kg}$ nitrogen $(\mathrm{N}) / \mathrm{ha}$ ) over the May/June period. This last financial year was the first time for over 10 years that the whole farm has had an annual dressing of P $1.2 \mathrm{~kg}$ available $\mathrm{P}$ per stock unit per ha. I applied DAP $13 \mathrm{~S}$ at $75 \mathrm{~kg}$ per ha and did the front half of the property last November and the back half in early April.

\section{Table 1 Physical summary}

\begin{tabular}{lcccc}
\hline Year Closing: & 1990 & 1991 & 1992 & 1993 \\
\hline Closing Stock: & & & & \\
Ewes & 2000 & 1850 & 1850 & 1550 \\
Hoggets & 420 & 676 & 650 & 1050 \\
Other & 55 & 48 & 70 & 30 \\
Sheep Stock Units & 2333 & 2357 & 2354 & 2306 \\
R1 Bulls & 170 & 772 & 162 & 168 \\
R2 Bulls & 201 & 199 & 190 & 208 \\
Cattle Stock Units & 1665 & 1663 & 1676 & 1712 \\
Total Stock Units & 4018 & 4040 & 4032 & 4018 \\
SU/eff ha (410 ha) & 9.8 & 9.8 & 9.0 & 9.8 \\
\hline
\end{tabular}

\section{Stockpol}

The following tables used in this paper are printouts from the computer program Stockpol produced when analysing my property. The Stockpol computer program was developed by AgResearch scientists led by Dave McCall who is based at Whatawhata. 
Table 2 Cattle liveweight gains and feed requirements (Stockpol computer Program)

\begin{tabular}{lcccccccccccc}
\hline & Jan & Mar & May & Jul & Sep & N o v & Jan & Mar & May & Jul & Sep & N o v \\
\hline Liieweight & 115 & 148 & 190 & 215 & 250 & 310 & 362 & 384 & 398 & 402 & 439 & 548 \\
LWG/kg/day & 0.5 & 0.7 & 0.6 & 0.2 & 0.8 & 1.2 & 0.4 & 0.3 & 0.1 & 0.0 & 1.8 & 1.8 \\
$\begin{array}{l}\text { Feed Requirement } \\
\text { kg DM/day }\end{array}$ & 2.3 & 3.4 & 3.7 & 2.7 & 5.2 & 7.4 & 5.1 & 4.8 & 4.2 & 3.8 & 12.1 & 14.0 \\
\hline
\end{tabular}

\section{Cattle}

I have been farming bulls since 1985 with the aim to kill them at $295 \mathrm{~kg}$ or better in the late spring/early summer. Prior to this I ran traditional and Friesian steers. The bull policy has also changed over time from basically running all rising Z-year-old cattle (up to 293 wintered) for a year to now buying in 170 weaners and some 18-month bulls each year so that I winter 208 rising 2-year-old cattle and 169 yearlings. The ratio does fluctuate between years but the overall stock units has stayed fairly similar over the last 4 years. The most important factor is the margin between the selling price and my replacement cost. This last year was a good one at $\$ 550$ which is $\$ 275$ per year. Each year some rising 2-year-old bulls are purchased to maintain the ratio of two year old cattle. My cattle achieve very average growth rates which I maintain is quite acceptable with a 2-year policy and it gives me a lot more management flexibility. I aim to achieve 1.8 $\mathrm{kg}$ liveweight gain per day over 80-90 days with my 2 year bulls in the spring. Over the late summer to early spring the 18-month to 2-year bulls' growth rates can vary from 0 to $0.4 \mathrm{~kg}$ per day.

\section{Sheep policy}

The breeding ewes are a Romney base but Border Leicester rams were used to give a first cross about 6 years ago. Traditionally most lambs would have been sold store but with some finished. The policy now is to take 500 wether hoggets through the winter which acts as a buffer mob. They are earmarked for live export but I suspect a number may be sold in October/ November on schedule if the money is good. I have dropped ewe numbers to take the extra wethers through. The main reason for the change is to have a genuine buffer mob of $8-10 \%$ of total stock units that can be held tight over the August to mid October period if feed is short. Up until now a mob of ewes would have been sacrificed to ensure the 2-year-old bulls are fed well in the spring. All indications to date point to the wether policy being a good income earner in its own right as well as fulfilling its buffer role.

Lambing begins in early September but I believe this could go back a week or two if the wether mob
Table 3 Ewe lamb to 2th liveweight gains and feed requirement (Stockpol)

\begin{tabular}{lcccccccc}
\hline & Jan & Mar & May & \multicolumn{3}{c}{ Jul Sep Nov Jan Mar } \\
\hline Liiewelght & 22 & 28 & 33 & 38 & 37 & 48 & 54 & $53^{\prime}$ \\
$\begin{array}{l}\text { LWG/grams/day } \\
\text { Feed Requirement }\end{array}$ & 72 & 72 & 70 & 40 & 85 & 145 & 100 & 50 \\
kg DM/day & 0.8 & 0.9 & 0.9 & 0.9 & 1.1 & 1.5 & 1.5 & 1.3 \\
\hline
\end{tabular}

Shorn

Table4 Mixed age ewes liveweight and feed requirement summary (Stockpol)

\begin{tabular}{lcccccc}
\hline & Jan & Mar & May & Jul & Sep & Nov \\
\hline Liieweight & 54 & $53^{\prime}$ & 54 & 53 & 47 & 49 \\
$\begin{array}{l}\text { Feed Requirement } \\
\text { kg DM/day }\end{array}$ & 1.3 & 1.1 & 1.0 & 1.1 & 1.4 & 2.9 \\
\hline Shorn & & & & & &
\end{tabular}

works out well and there is still very good profit in cattle.

The 'shearing policy has been 8-month split flock with the ewes for the last 8 years. Wool production has been disappointing at $4.3-4.5 \mathrm{~kg}$ per sheep stock unit over the last 4 years but this is fairly typical of most Wairarapa properties since the drought in 1988/89. I have changed the timing of shearing this year to get away from shearing lambs at foot. It will mean prelamb shearing in July/August instead of the usual May period but I don't anticipate any problems with only 800 to shear and the use of cover combs.

\section{Risk management}

For most farmers risk management should be an important part of their farming philosophy. The major risks facing me are soil wetness, price fluctuations and variable summer growth.

Wet winters are a fact of life on my property. When I was running only 2-year-old bulls I considered the risk of a very wet winter and hence pugging damage with the heavy cattle too great, hence the change to the present policy of running a mix of 1- and 2-year-old cattle. I have further refined this with the wether mob this last winter which can be held very tight until mid 
October without, I hope, affecting their earning ability. The yearling cattle can also be done fairly hard over the August/September period if required.

To minimise the effects of price fluctuations $I$ am happy to enter into contracts to buy and sell stock that achieve my budget targets and reduce risk. My 8 month split flock shearing policy is also a hedge against the price fluctuations because I end up selling five main lots of wool throughout the year, This last year I generally sold my cattle a lot lighter than usual because the price was right. The last 20-40 bulls I sell are replaced so the margin is just as important as the final price. Traditionally I have sold a lot of light lambs when the Alpha schedule was paying good money.

\section{Grazing management}

Dry summers have to be planned for, although the pasture production can be extremely variable. I aim to be down to my winter stock numbers as early in the new year as possible with the objective of carrying the maximum amount of autumn growth into the winter. Feed quality can be a major problem especially in a growthy summer. It is hard to maintain good feed quality on the cattle blocks over the November/December period. To achieve top growth rates with the 2-year-old cattle usually means that their pastures will get out of control. If this is not addressed before it gets dry it will be a battle over the next 3 to 12 months to get this tidied up. Ideally I would like to swap my older bulls onto the yearling blocks and my sheep country over the late October/November period to enable the sheep to graze on the 2-year-old cattle blocks.

I aim to rotational graze as much as possible. The various classes of sheep and cattle get weighed frequently and this information is used when making both selling and grazing management decisions.

Starting with lambing, the ewes are set stocked from late August or at lamb drop through to weaning in late November/early December. They are then shuffle grazed until April on a 30- to 50-day rotation with the aim of putting weight on them, ideally to achieve tupping weight by Christmas/mid January but also to clean up some pastures over the late summer. From early May they head out to a 100-day rotation but it has been a struggle in the previous 3 years to get the rotation length better than 80 days. I went into last winter in a good feed situation so should actually achieve close to my 100-day target. The lambs and weaners are shuffled where the best feed is over the summer to early winter period. From mid winter through to early summer they are usually block grazed on their own areas. With my present policy I have a high proportion of young stock on the farm (35\% of total stock units) which can complicate the management. Some of them can be a lower priority if the need arises.

The cattle are run in big mobs of 70-90 from weaners through until they go onto an intensive block grazing system in July as a rising 2 year old. They are generally shuffled grazed over the late spring to early winter period as weaners and 18-month cattle. As an 18-month animal I am prepared to make them work to clean up country to maximise the autumn growth and to take better quality feed into the winter. I often run a bull mob either in with or associated with my main ewe mob. With the lower ewe numbers it helps to increase the grazing pressure and do a better clean up job and make it easier to get onto a long winter rotation. Over the May/June period this year the main grazing mob consisted of 1600 ewes and 85 bulls or $50 \%$ of my total stock units. The grazing pressure in this mob was 1000 stock units per ha per day. The bull mob in with the ewes can be swapped if I feel they have been under too much pressure. The other big bull mob will be cleaning up say four to six paddocks over the same time. A top bull mob is usually kept going to give me earlier selling options in the spring. From July onwards they are block grazed in mobs of 50 2-year-old bulls to 20 ha through to the late spring period. Ideally in October I would reduce the mob size down to around 30 and they would be fed ad lib. The yearling cattle are block grazed in the bigger mobs over the late winter/spring period.

\section{Pasture production}

MAF Research technician Terry Wyeth was involved with some trials in the early 1980s when pasture growth rates were measured. From his work and other Wairarapa data I have estimated the monthly pasture growth rates for Middlespur (Table 5). What came out of the pasture measurements is the large variation between years especially over the November to March period.

Table 5 Pasture growth and demand

\begin{tabular}{|c|c|c|c|c|c|c|c|c|c|c|c|c|c|}
\hline & Jan & Feb & Mar & Apr & May & Jun & Jul & Aug & Sep & Oct & Nov & $D_{\theta C}$ & $\begin{array}{l}\text { Total DM } \\
\text { Production }\end{array}$ \\
\hline $\begin{array}{l}\text { Pasture Growth Rate } \\
\text { kq DM/ha/day }\end{array}$ & 10 & 10 & 10 & 20 & 20 & 10 & 5 & 12 & 35 & 55 & 50 & 30 & 8116 \\
\hline $\begin{array}{l}\text { Pasture Supply } \\
\text { Stock Demand } \\
\text { Balance }\end{array}$ & $\begin{array}{l}7.2 \\
13.3 \\
-6.2\end{array}$ & $\begin{array}{c}7.7 \\
11.3 \\
-3.6\end{array}$ & $\begin{array}{l}6.9 \\
11.9 \\
.3\end{array}$ & $\begin{array}{l}16.6 \\
11.7 \\
6.9\end{array}$ & $\begin{array}{l}16.6 \\
10.1 \\
6.5\end{array}$ & $\begin{array}{l}9.4 \\
9.3 \\
0.1\end{array}$ & $\begin{array}{c}4.7 \\
9 \\
-4.3\end{array}$ & $\begin{array}{l}10.1 \\
10.6 \\
-0.5\end{array}$ & $\begin{array}{c}26.1 \\
16.3 \\
9.7\end{array}$ & $\begin{array}{c}39 \\
19.4 \\
19.6\end{array}$ & $\begin{array}{r}30.3 \\
20.3 \\
10\end{array}$ & $\begin{array}{c}20.6 \\
16.4 \\
4.3\end{array}$ & \\
\hline
\end{tabular}


Table 6 Percentage of total feed demand used by sheep and cattle

\begin{tabular}{|c|c|c|c|c|c|c|c|c|c|c|c|c|c|c|}
\hline & Jan & $\mathrm{Feb}$ & Mar & Apr & May & Jun & Jul & Aug & Sep & Oct & Nov & Dec & \multicolumn{2}{|c|}{$\begin{array}{l}\text { Monthly Ratic } \\
\text { Average SU }\end{array}$} \\
\hline Sheep & 68 & 69 & 64 & 61 & 62 & 63 & 66 & 59 & 49 & 56 & 61 & 65 & 62 & 57 \\
\hline Cattle & 32 & 32 & 36 & 39 & 38 & 37 & 34 & 41 & 51 & 44 & 39 & 35 & 38 & 43 \\
\hline
\end{tabular}

\section{Stock units}

I have stuck to the traditional stock unit system. I have found them reasonably accurate for my cattle policy where I am not after maximum growth rate. On the Stockpol model the cattle consume $38 \%$ of the feed and the sheep $62 \%$ on a 12-month basis (Table 6). On a stock unit basis the cattle make up $43 \%$. The monthly cattle feed demand ranges from $51 \%$ in September to only $32 \%$ in January/February. The actual feed demand goes from $9 \mathrm{~kg}$ of dry matter per day in July to a peak of $20 \mathrm{~kg}$ dry matter per day in November.

\section{Conclusion}

Financially successful Wairarapa hill country farmers are operating a wide range of stock policies and sheep to cattle ratios to achieve an economic farm surplus of $\$ 150-\$ 250$ per ha. My high ratio of 1 - and 2-year-old bulls and accepting average performance is just one way of farm profitability. There is still scope to lift per head and per ha production by $10 \%$ on most of these properties. 